\title{
SCHOOL AUTONOMY AND SCHOOL LEADERSHIP: CASE STUDY OF SCHOOL OPERATION IN SLOVAKIA
}

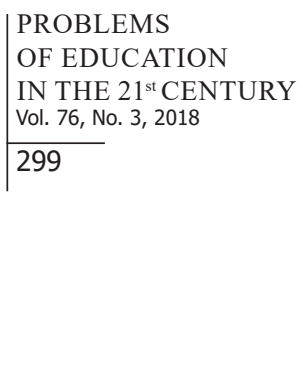

\author{
Alena Hašková \\ Constantine the Philosopher University in Nitra, Slovakia \\ E-mail: ahaskova@ukf.sk \\ Miriam Bitterová \\ Agromart, Trakovice, Slovakia \\ E-mail: bitterova@agromart.sk
}

\begin{abstract}
During as near as three decades after the political changes in Slovakia its system of education has undergone many reforms. As an integral part of them have been changes regarding school autonomy as it influences quality of education. To achieve an optimal model of autonomy offered to schools is very difficult, as appropriate level of autonomy is dependent on time and social conditions. To improve democratic participation of primary and secondary school leaders in Slovakia, a research aimed at assessment of the current state of the level of school autonomy was carried out. The research data were obtained from a questionnaire survey, the respondents of which were 93 headmasters and deputy headmasters. These school leaders assessed the power they (the schools) have in five fields, namely in the fields of school activity in the whole, school curricula matters, school financing and budgeting, staff recruitment, selection, employing and sacking, administrative and operational management. The assessment they give once with respect to the level in which to them given autonomy matches the tasks and problems they have to cope with, and the second time with respect to their opinion where the scope of the autonomy should be changed. Although the school leaders assessed the level of the powers they are given in a positive way, as average or broader, they still feel a need to have a broader scope of the powers and responsibilities, mainly in the field of financing and budgeting.
\end{abstract}

Keywords: power extension, school autonomy, school deliberation, school leaders.

\section{Introduction}

After the political changes in Slovakia schools have undergone many reforms. An integral part of them have been changes regarding also autonomy of the system of education (Act 596/2003). Although the reform process of school deliberation has been going on for several decades, school autonomy remains a key issue of school management, as it strongly influences quality of education and pupils and students` learning achievements.

With a greater autonomy given to schools, school leaders face much greater responsibility than school leaders did twenty years ago. The autonomy of schools and responsibility of school leaders are not the subject only of financial and administration matters of the school (i.e. subject of its operation), but they are as well the subject of the offered education matters (i.e. subject of its action regarding new study programme introduction, curricula and teaching method innovation, sustainable education quality improvement, etc.). School leaders face a great accountability for school and student results, responsibility for contributing to and supporting the school local communities, other schools and other public services. Quality of leadership has been currently 
Alena HAŠKOVÁ, Miriam BITTEROVÁ. School autonomy and school leadership: Case study of school operation in Slovakia

PROBLEMS

OF EDUCATION

IN THE $21^{\text {st }}$ CENTURY Vol. 76, No. 3, 2018

300

recognized as an important aspect of each school operation, influencing its outcomes and its students' achievements (Lhotková, Trojan \& Kitzberger, 2012). School leadership has become also an education policy priority across OECD and partner countries (Pont, Nusche \& Hopkins, 2008; Pont, Nusche \& Moorman, 2008). In this context the most often discussed and observed topic is the question of the relevant professional competences (knowledge, skills, attitudes) a school leader should dispose. Answers to this question should result from empirically founded findings reflecting the real needs and demands of practice (Bitterová, Hašková, Pisoňová, Obdržálek, Polák, Lančarič \& Horváthová, 2011). That is why a lot of researches have been focused in this direction (NCSL, 2006; Revai \& Kirkham, 2013; Whitaker, 2002). On the other hand, only a little attention is paid to the assessment of the real state of the school autonomies in the context of the current needs and requirements of the practice.

Leadership practice can be understood in a narrower or broader context. In a narrower understanding of this term we look at leadership practice from the point of view of a particular place and time and in a broader meaning we look at leadership practice as at a component part of an overall system of practice that is influenced not only by the immediate situation, the ordinary everyday life conditions, and sometimes also extraordinary, interactions in an institution or company, but also the broader contextual and social influences. In this meaning it can be differentiated between performance and financial powers and responsibilities of leaders. Performance management involves such tasks as setting goals and objectives of the institution, their implementation, measuring and reporting on performance, making informed decisions based on outcomes and sharing information. Financial management covers operation of systems for budget-making and implementation, maintenance of an accounting system, maintenance of the buildings and the institution operation, recording decisions, transactions and audits. School leadership is no exception of the mentioned (MacBeath, 2006; Spilane, 2006). But there is a great difference between the environments in which the national systems of education (mainly those in Central and East European countries) existed in the previous century and exist nowadays. Under the changing social and economic conditions at the end of $20^{\text {th }}$ century a great deal of responsibilities was passed from the central authorities to local municipalities and particular schools. Changed conditions and increased autonomy of schools have meant that schools have faced new tasks and challenges in the following four fields:

- financial management under the influence of the autonomy given to schools,

- educational changes under the influence of re-assessed and redefined character and mission of schools,

- public management under the influence of changed approach from bureaucratic and institution-led approach towards a performance-driven approach with an emphasis on the services delivered to their users,

- knowledge management under the influence of the institution's own need and demand for continuous learning.

The above-mentioned tasks and challenges, which schools have faced to, result in new requirements on school leaders' professional profile. Changed conditions and increased autonomy of schools call for new professional competences of school leaders. While before a school leader represented a practising teacher with added technical and administrative duties, a now a day school leader should be a professional, a full-time manager responsible for and developing instructional, human, financial and physical resources to ensure sustainable quality of the education which the school offers and provides. The mission of the school leaders has become to cope successfully with managing changes and school improvement. Unfortunately, these issues have often been strongly influenced by fast-changing governments and their politics. And that is why in the common practice a school leader does not very often act so much as a leader of the school as an institution, as an administrator in a wider bureaucratic school system. One of the practical reasons of this situation can be a non-adequately assigned level of authority for schools. 
It is clear that to achieve an optimal model of autonomy offered to schools is very difficult. But one should still try to bring the reality as close to an optimal state as possible. Moreover, a model of an optimal autonomy is a dynamic element, dependent on time and social conditions. So from the mentioned, it results that the need to improve democratic participation of particular stakeholders at managing the system of education - and in this way to improve quality of teaching - should still remain in attention of the national education policy. And this is not only the case of Slovakia, education policy of each country should constantly pay attention to this issue (Bush \& Glover, 2003; EURYDICE, 2007; Leithwood, 2001; OECD, 2001a; OECD, 2001b; OECD, 2003; Townsend, 2007).

To estimate how much autonomy has been currently given to schools in Slovakia and whether this amount of autonomy has been sufficient for the in-service school leaders, a research was carried out and in frame of it opinions of school leaders to this issue were collected. The main research question was whether the scope of the powers delegated to schools is consistent with the needs and conditions of school leadership practice, i.e. whether the current scope of the school autonomy matches the task and problems the school leaders have to cope with in the common every day practice of their school management. From the main research question two partial questions resulted. In particular these were the following ones:

- research question 1: Which powers and responsibilities of schools should be increased?

- research question 2: Which powers and responsibilities of schools should be decreased?

\section{Research Methodology}

\section{General Background}

Practice of school leaders cannot be investigated as a function of the mental capacity of the individuals because practice is enabled and constrained by the situation in which it takes place (Resnick, 1991) and it is imperative to investigate the school leadership practice in its natural environment, in the common conditions it takes place (Hutchins, 1995; Leontjev, 1995). That is why it was decided to focus attention on the autonomy aspects of the broader social environment in which the Slovak schools operate. In particular the attention was focused on primary and secondary schools (ISCED $1-3$ ) and the adequacy of autonomy currently given to these schools (school leaders of these schools) was assessed in five fields of school leadership. List of the five observed fields F1 - F5 is presented in Table 1.

Table 1. Fields in which the extent of school autonomy was assessed.

\begin{tabular}{ll}
\hline Item & Field \\
\hline F1 & School activity in the whole \\
\hline F2 & School curricula matters \\
\hline F3 & School financing and budgeting \\
\hline F4 & Staff recruitment, selection, employing and sacking \\
\hline F5 & Administrative and operational management \\
\hline
\end{tabular}

The structure of the fields of powers given to school leaders (school autonomy) F1 - F5, in which the adequacy of the scope of powers and responsibilities were surveyed, are in agreement e.g. with Urbanovič (2011), who specifies autonomy of schools in management autonomy (i.e. organizing activities, administrative and operational management, school activities in the 
Alena HAŠKOVÁ, Miriam BITTEROVÁ. School autonomy and school leadership: Case study of school operation in Slovakia

PROBLEMS

OF EDUCATION

IN THE $21^{\text {st }}$ CENTURY Vol. 76, No. 3, 2018

302

whole), pedagogical or teacher autonomy (i.e. curriculum and organization of teaching process), staff autonomy (i.e. human resource management, staff recruitment, selection, employing and sacking), financial autonomy (i.e. management of school assets, school financing and budgeting) and external factors (i.e. relations with other schools and governmental institutions), or with the approaches to this phenomena which were used in frame of the carried out PISA and TALIS international monitoring (OECD-PISA, 2012; OECD-TALIS, 2013), where four major fields of school autonomy are specified, in particular instructional policies (e.g. curriculum and assessment), staffing, budgeting and student policies.

\section{Instruments and Procedure}

To find out answers to the research questions as a tool of the data collection a questionnaire consisting of five items was used. Each of the questionnaire items referred to one of the school leadership key fields presented in Table 1. In the task of the questionnaire survey, the respondents were to assess adequacy of the power they (the schools) have within each of the given five fields (items F1 - F5). Respondents passed through these items twice and each time they gave their responses to them from another point of view:

1. At first, the respondents expressed their opinions on a current real state of the power they have. They evaluated how broad possibilities this power gives them to act on behalf of the school they manage in the particular key fields of the school leadership. The respondents were asked to express their opinion using a 5-point scale: 1 minimal powers; 2 - little powers; 3 - average powers; 4 - broad powers; 5 - very broad powers.

2. Secondly, the respondents (the same in-service school leaders) expressed their opinions on an optimal state of the power they (the schools) should have in the particular key fields of the school leadership. The respondents were asked to express their verdicts whether the current scopes are adequate or whether they should be extended or reduced.

In Slovakia, only persons with qualification for teaching or professional training performance can be appointed into a position of the school leader and these nominees are obliged to complete so-called functional education (school leader career training) at latest within three years from being placed in this career position (Act 317/2009). This education is organised by the Methodology and Pedagogy Centre (Institution for Teacher's Education and Training), which is a budget organization of the Ministry of Education, Science, Research and Sport of the Slovak Republic). Validity of the functional education is for a maximum of seven years after its completion and its validity is prolonged after each graduation of the functional innovation education which is completed before expiration of the functional education or functional innovation education validity. Functional innovation education is valid for five years after its completion. To create a representative research sample the questionnaires were administrated in cooperation with The Methodology and Pedagogy Centre to participants of the functional education organized by this Centre.

\section{Research Sample}

Based on the above-mentioned cooperation with the Methodology and Pedagogy Centre the research sample consisted of 93 participants of the functional education of the teaching staff and vocational training employees (Act 317/2009). Description of the research sample is presented in Table 2. 
Table 2. Description of the research sample.

\begin{tabular}{ll}
\hline Age & - from 26 up to 61 - year-old, average 47.3 \\
\hline Gender & -26 males, 67 females \\
\hline Career position & $\begin{array}{l}-42 \text { headmasters, } 51 \text { deputy headmasters (of schools } \\
\text { and school facilities) }\end{array}$ \\
\hline $\begin{array}{l}\text { Previous practice } \\
\text { in a leading position }\end{array}$ & \begin{tabular}{l}
-34 respondents less than 5 years, 27 respondents from 14 years, 32 respondents more than 15 years \\
\hline Kind of the school
\end{tabular} \\
\hline $\begin{array}{l}\text { School size according to } \\
\text { the number of teachers }\end{array}$ & \begin{tabular}{l} 
ary schools, 14 art schools \\
\hline $\begin{array}{l}\text { School size according to } \\
\text { the number of students }\end{array}$
\end{tabular} \\
\hline
\end{tabular}

The numbers of males and females presented in the research sample express ratio of male and female teachers working at primary and secondary schools what is consequently also reflected in the leading positions of this school management.

From the statistical point of view, there are approximately equal numbers of headmasters and deputy headmasters, as well as school leaders with the different lengths of previous practice in the leading positions.

As in Slovakia primary education (ISCED 1) and lower secondary education (ISCED 2) are carried out in an integrated so-called basic school (followed by a secondary school - ISCED 3 ), there is a higher number of school leaders representing this kind of schools in the research sample. But in the sub-group of these respondents there were both school leaders - teachers of primary education as well as school leaders - teachers of lower secondary education.

\section{Data Analysis}

The obtained research data were processed at first by the means of descriptive statistics (see the results in Table 2 and Table 3 ) and secondly by the means of Kruskal-Wallis test and Mann-Whitney $U$ test to find significant differences among the particular sub-groups of the respondents according to their main characteristics - factors gender, career position and previous practice in a leading position (see the results in Table 4). Occurrence of the statistically significant differences was observed on the statistical significance level $\mathrm{p}<.05$ which is a standard level of significance.

\section{Research Results}

Results obtained from the processing of the research data are summarized in Tables 3 - 5 .

Table 3 shows that average score values for all items are within the interval from 2.87 to 3.89 , i.e. the school leaders evaluate the scope of the powers they have as average or broader. In their opinion the broadest scope of powers they have in the field of administrative and operational management. 
PROBLEMS

OF EDUCATION IN THE $21^{\text {st }}$ CENTURY Vol. 76, No. 3, 2018

304

Table 3. Descriptive statistics of the assessment score of the extent of school autonomy in the particular fields of school leadership.

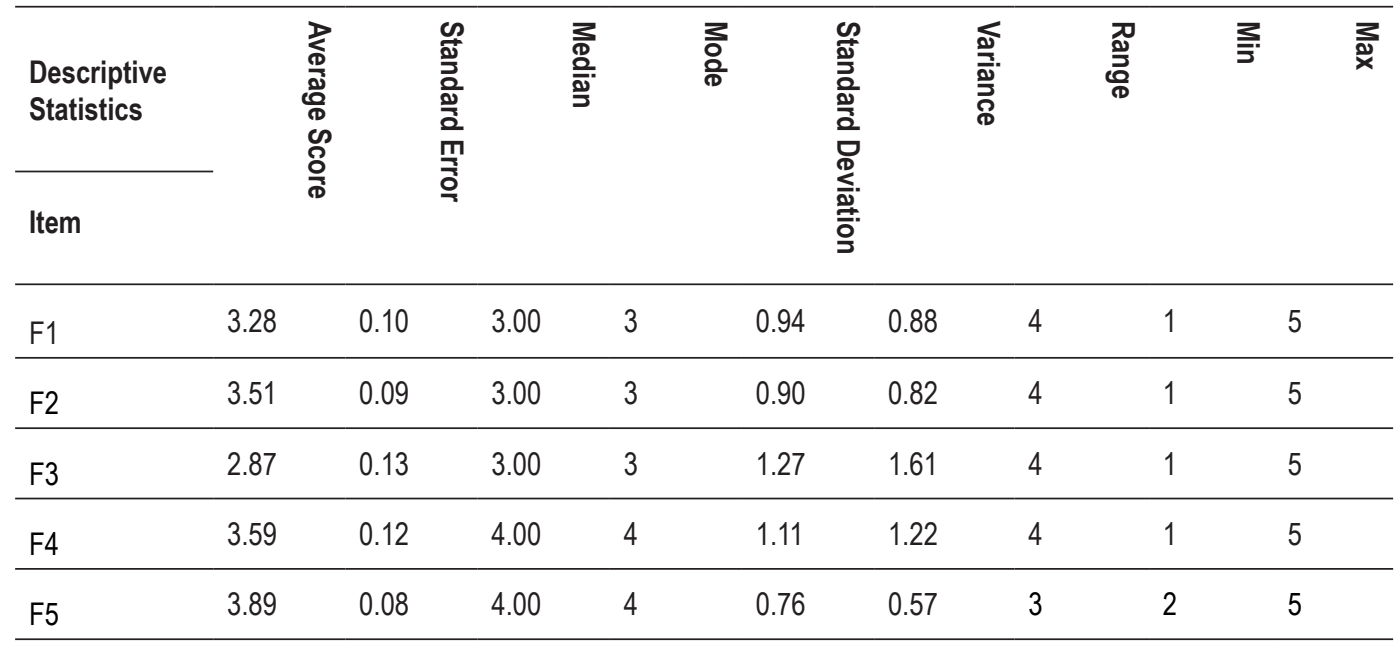

Despite the expressed positive assessment of the scope of the powers the school leaders have, they still feel a necessity to broaden these scopes, at least a half of the respondents - see Table 4, items F2 - 49.5\%, F4 - 53.8\%; F1 - 67.7\%, F3 - $79.6 \%$.

The only exception from the call for extension of the powers is the item F5 - extent of powers and autonomy in the field of administrative and operational management. The respondents assess the extent of powers and autonomy in this field as almost broad (F5 - 3.89): $65.6 \%$ of the respondents assess them as appropriate ones, only $30.1 \%$ would like to have them increased and $4.3 \%$ would like even to decrease them.

The highest demand for an increased extent of the powers and autonomy is at the item related to the field of the school financing and budgeting. In this field the respondents declare also the lowest level of powers given to them. The opinion that to reach an optimal state in school managing in Slovakia needs to broaden the current extent of powers and autonomy in the field of the school financing and budgeting share almost three thirds of the respondents (F3-79.6\%).

Table 4. Demands to change current extent of school leader powers and school autonomy.

\begin{tabular}{|c|c|c|c|c|c|c|}
\hline \multirow[b]{2}{*}{ Item } & \multicolumn{2}{|c|}{ Decrease the autonomy } & \multicolumn{2}{|c|}{ Adequate autonomy } & \multicolumn{2}{|c|}{ Increase the autonomy } \\
\hline & 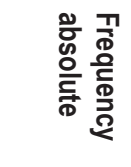 & 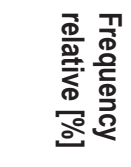 & 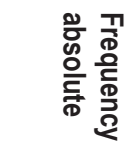 & 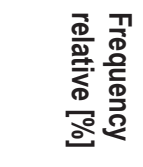 & 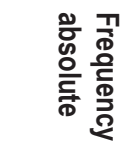 & 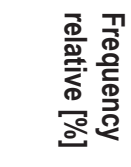 \\
\hline F1 & 0 & 0.0 & 30 & 32.3 & 63 & 67.7 \\
\hline F2 & 6 & 6.5 & 41 & 44.1 & 46 & 49.5 \\
\hline F3 & 2 & 2.2 & 17 & 18.3 & 74 & 79.6 \\
\hline F4 & 3 & 3.2 & 40 & 43.0 & 50 & 53.8 \\
\hline F5 & 4 & 4.3 & 61 & 65.6 & 28 & 30.1 \\
\hline
\end{tabular}


Overview of the results of the tests (Mann-Whitney U, Wilcoxon W and Chi Square) which were used to test differences among the responses of the particular sub-groups of the research sample according to the factors gender, career position and previous practice in a leading position is presented in Table 5 .

Table 5. Mann-Whitney $U$ test results for the particular items F1 - F5 in dependency on the factors gender, career position and previous practice in a leading position.

\begin{tabular}{|c|c|c|c|c|c|c|}
\hline Item & & F1 & F2 & F3 & F4 & F5 \\
\hline \multicolumn{7}{|l|}{ Factor } \\
\hline \multirow[b]{4}{*}{ Gender } & Mann-Whitney U & 822.000 & 739.500 & 837.000 & 825.500 & 845.500 \\
\hline & Wilcoxon W & 3100.000 & 3017.500 & 3115.000 & 3103.500 & 1196.500 \\
\hline & Z & -0.443 & -1.191 & -0.301 & -0.405 & -0.238 \\
\hline & $\mathrm{p}$ & .658 & .234 & .764 & .685 & .812 \\
\hline \multirow[b]{4}{*}{$\begin{array}{l}\text { Career posi- } \\
\text { tion }\end{array}$} & Mann-Whitney U & 931.500 & 1058.500 & 890.000 & 1047.000 & 985.500 \\
\hline & Wilcoxon W & 1834.500 & 2384.500 & 1793.000 & 1950.000 & 1888.500 \\
\hline & Z & -1.136 & -0.102 & -1.444 & -0.193 & -0.721 \\
\hline & $p$ & .256 & .919 & .149 & .847 & .471 \\
\hline \multirow{3}{*}{$\begin{array}{l}\text { Practice in } \\
\text { a leading } \\
\text { position }\end{array}$} & Chi-Square & 4.905 & 3.886 & 3.532 & 7.595 & 2.361 \\
\hline & $d f$ & 2 & 2 & 2 & 2 & 2 \\
\hline & p & .086 & .143 & .171 & .022 & .307 \\
\hline
\end{tabular}

As Table 5 shows, the tests did not confirm any outstanding differences among the responses of the particular sub-groups of the respondents.

\section{Discussion}

The answer to the main research question, whether the scope of the powers delegated to schools is consistent with the needs and conditions of school leadership practice, follows from the finding that school leaders evaluate the scope of the powers they have as average or broader. On the other hand, although the school leaders assessed the level of the powers they are given in a positive way (as average or broader), they still feel a need to have a broader scope of the powers and responsibilities, mainly in the field of financing and budgeting (the field in which, in their opinion, they have the lowest level of powers). The second strongest call for the increase of the autonomy was recorded in connection with the field F1 (school activity in the whole). Calls to decrease the scope of powers given to schools were isolated in case of all five assessed autonomy fields. So, the answer to the main research question is: yes, the scope of the powers delegated to schools is sufficient. Answers to the particular research questions 1 and 2 show whether there is a need to optimize in some way the present state of school autonomy. Following the opinions of the school leaders such a need does exist, because the answer to the particular research question 1 is that increased should be powers and responsibilities of schools in all of the five given fields (a need to decrease any of the given fields does not occur).

As reviewed by the Grattan Institute (2013), a wide range of international studies shows that the direct influence of increased autonomy on learning achievements of students 
Alena HAŠKOVÁ, Miriam BITTEROVÁ. School autonomy and school leadership: Case study of school operation in Slovakia

PROBLEMS

OF EDUCATION

IN THE $21^{\text {st }}$ CENTURY Vol. 76, No. 3, 2018

306

the other hand, in PISA and TALIS monitoring there were recorded school headmasters' opinions confirming existence of this influence (OECD, 2012; OECD, 2013). Moreover, as the data gathered in PISA 2009 monitoring showed, when autonomy and accountability are combined well, they tend to be associated with better student performance (OECD, 2011). Conceptually, leadership and autonomy can interact in two ways: autonomy allocated to a school may restrict the scope of leadership in daily operations or the ability to launch new initiatives, or leadership activities may be implemented to maximize the use of autonomy allocated to a school, remove existing limitations, broaden the scope of school autonomy and create better conditions for school development and student learning (Cheng, Ko \& Hoi Lee, 2016).

In the analysis of the respondents' responses in dependency on the factors of their gender, career position they hold, and duration of their previous practice in the leading position only two cases of differences between the particular sub-groups of the respondents were identified.

The first one is different assessment of the need to change the current scope of administrative and operational management declared by the group of headmasters and the one declared by the group of deputy headmasters (headmasters' requirement to increase the powers versus deputy headmasters' satisfaction with the current state). The total results for the whole group (results of the descriptive statistics) showed that the item F5, administrative and operational management, is assessed as a field in which the autonomy and powers given to schools and school leaders are the highest ones and consequently there is the smallest level of demand to increase them. But, nevertheless, this demand does exist here. Analysis of the results according their dependency on the particular factors shows that those who would appreciate even broader powers in the field of the administrative and operational management (which are already quite broad) are headmasters. Deputy headmasters consider the level of school autonomy in this field as an appropriate one, and they are satisfied with it.

The second difference occurs between the opinions of the group of school leaders with $5-14$ year practice in a leading position and the groups of the school leaders with a shorter or longer practice on the current level of autonomy and powers in the field of staff recruitment, selection, employing and sacking (opinion that the powers are broad vs. opinion that they are average). Respondents with $5-14$ year duration of the previous practice in a leading position assess the current level of the autonomy and powers in this field as broad (average score 4.07) while the other two groups of the respondents (i.e. the respondents with previous practice in a leading position less than 5 years and the respondents with this practice more than 15 years) assess it as an average one (3.41 and 3.38).

In this context it is important to point on the fact that as to the school leaders` opinions about the school autonomy, there didn't occur any significant differences between the male and female respondents, although many researches on school leadership prove differences in masculine and feminine leadership styles (Gray, 2006; Guramatunhu-Mudiwa \& Bolt, 2012; Krüger, 2008).

\section{Conclusions}

Currently school autonomy is considered to be an important factor influencing further development of schools and improvement of school practices. It results from the fact that a higher level of autonomy offers to schools greater possibilities to meet changing expectations of their stakeholders and increasing call for high quality education relevant to up-to-date requirements in a flexible and prompt way (e.g. fast introduction of curricular and pedagogical changes that enhance students' learning). Schools in different education systems are often given different levels of autonomy in their particular fields and the extent to which this autonomy is used by schools may vary, too. As the results of the presented research show, in Slovakia school 
leaders assess the current range of the school autonomy as sufficient but on the other hand they would appreciate to have it even broader - mainly in case of the area of school financing and budgeting, followed by the areas of school activity in whole, staff recruitment, selection, employing and sacking, and school curricula matters. The finding, resulted from opinions of a representative research sample one of the most important group of the school stakeholders, can serve (or should be taken into consideration) as a platform for the relevant decision makers and designers of the national school policy to define a strategy for further development of the national system of education and in frame of it to optimize also autonomy of schools.

\section{References}

Act No. 317/2009 Coll. on Teaching Staff and Vocational Training Employees (Act of the National Council of the SR). Available from: https://www.slov-lex.sk/pravne-predpisy/SK/ZZ/2009/317/20170901. html.

Act No. 596/2003 Coll. on State Administration in Education and School Self-government (Act of the National Council of the SR). Available from: https:/www.slov-lex.sk/pravne-predpisy/SK/ ZZ/2003/596/20170901.

Bitterová, M., Hašková, A., Pisoňová, M., Obdržálek, Z., Polák, J., Lančarič, D., Šimková, Z., Laššák, V. \& Horváthová, K. (2011). Otázky koncepcie prípravy riadiacich zamestnancov škôl [Issues of school leader training concept]. Nitra, PF UKF.

Bush, T., \& Glover, D. (2003). School leadership: Concepts and evidence. Nottingham, NCSL.

Cheng, Y. Ch., Ko, J., \& Hoi Lee, T. T. (2016). School autonomy, leadership and learning: A reconceptualization. International Journal of Educational Management, 30 (2), 177-196. https:// doi.org/10.1108/IJEM-08-2015-0108.

EURYDICE (2007). School autonomy in Europe: Policies and measures, Comparative Study. Brussels, Eurydice.

Grattan Institute (2013). The myth of markets in school education. Victoria, Grattan Institute.

Gray, H. L. (2006). Gender considerations in school management: Masculine and feminine leadership styles. School Organisation, 7 (3), 297-302. doi: 10.1080/0260136870070305.

Guramatunhu-Mudiwa, P., \& Bolt, L. L. (2012). Does the gender of school personnel influence perceptions of leadership? School Leadership and Management, 32 (3), 261-277, doi: 10.1080/13632434.2012.688742.

Hutchins, E. (1995). Cognition in the wild. Cambridge, MIT Press.

Krüger, M. L. (2008). School leadership, sex and gender: Welcome to difference. International Journal of Leadership in Education, 11 (2), 155-168, doi: 10.1080/13603120701576266.

Leontjev, A. N. (1981). Problems of the development of the mind. Moscow, Progress Publishers.

Lhotková, I., Trojan, V. \& Kitzberger, J. (2012). Kompetence ř́dicích pracovníků ve školství [Competences of school leaders]. Praha, Wolters Kluwer.

MacBeath, J. (2006). Leadership as distributed: A matter of practice, School Leadership and Management, 25(4), 349-366, doi: 0.1080/13634230500197165.

Leithwood, K. (2001). School leadership in the context of accountability policies. International Journal of Leadership in Education, 4 (3), 217-235. doi: 10.1080/13603120110057082.

NCSL (National College for School Leadership) (2006). Leadership Succession: An Overview: Securing the Next Generation of School Leaders. Nottingham, NCSL.

OECD (2003). Networks of innovation: Towards new models of managing schools and systems. Paris, OECD.

OECD (2001a). Public sector leadership for the 21st century. Paris, OECD.

OECD (2001b). What works in innovation in education: New school management approaches. Paris, OECD.

OECD (2011). PISA in Focus. School autonomy and accountability: Are they related to student performance? OECD Publishing.

OECD (2012). PISA 2012: Principal questionnaire data file. Available from: http://pisa2012.acer.

edu.au/ downloads.php. 
Alena HAŠKOVÁ, Miriam BITTEROVÁ. School autonomy and school leadership: Case study of school operation in Slovakia

PROBLEMS

OF EDUCATION

IN THE $21^{\text {st }}$ CENTURY
Vol. 76, No. 3, 2018

308

OECD (2013). TALIS 2013 results: An international perspective on teaching and learning. Available from: www.oecd.org/edu/school/talis.htm.

Pont, B., Nusche D., \& Moorman, H. (2008). Improving school leadership, vol. 1: Policy and Practice. Paris, OECD.

Pont, B., Nusche, D., \& Hopkins, D. (2008). Improving school leadership, vol. 2: Case studies on system leadership. Paris, OECD.

Resnick, L. B. (1991). Shared cognition: thinking as social practice, Perspectives on Socially Shared Cognition. Washington, American Psychological Association.

Revai, N., \& Kirkham, G. A. (2013). The art and science of leading a school, Central 5: A Central European view on competencies for school leaders. Budapest, Tempus Public Foundation.

Spilane, J. (2006). Distributed leadership. San Francisco: Jossey-Bass.

Townsend, T. (2007). International handbook of school effectiveness and improvement. Dordrecht, Springer.

Urbanovič, J. (2011). School leadership and autonomy. Vilnius: Mykolas Romeris University. Available from: http://pages.pedf.cuni.cz/uvrv/files/2015/06/Jolanta_Urbanovic_11_06_15.pdf.

Whitaker, K. (2002). Principal role changes and influence on principal recruitment and selection, An international perspective, Journal of Educational Administration, 41 (1), 37-54, doi: $10.1108 / 09578230310457420$.

Received: March 06, 2018

Accepted: May 22, 2018

Alena Hašková

$\mathrm{PhD}$, Professor, Constantine the Philosopher University in Nitra, Tr. A. Hlinku 1, 94974 Nitra, Slovakia.

E-mail: ahaskova@ukf.sk

Miriam Bitterová

Research and Project Manager, Agromart, Trakovice, Slovakia.

E-mail: bitterova@agromart.sk 